\title{
ANALYSIS A CUTTING EDGE GEOMETRY INFLUENCE ON CIRCULAR SAW TEETH AT THE PROCESS OF CROSSCUTTING WOOD
}

\author{
J. Kováč, M. Mikleš
}

Received: June 5,2009

\begin{abstract}
KOVÁČ, J., MIKLEŠ, M.: Analysis a cutting edge geometry influence on circular saw teeth at the process of crosscutting wood. Acta univ. agric. et silvic. Mendel. Brun., 2009, LVII, No. 5, pp. 177-182

Nowadays, the wood cutting process looks like a technological scheme consisting of several connected and relatively inseparable parts. The crosscutting wood is the most widespread in the process of forest exploitation; it is used at tree exploitation, shortening stems and assortment production. The article deals with the influence of the cutting edge geometry of circular saws on the torque and also on the cutting performance at the crosscutting wood therefore there is the influence on the whole cutting process. In the article there is described detailed measurement procedure, used measuring devices and the process of results analysis. Knowledge of wood crosscutting process and choice of suitable cutting conditions and cutting tools will contribute to decrease production costs and energy saving.
\end{abstract}

crosscutting wood, circular saw, cutting edge geometry, cutting power

\section{INTRODUCTION}

The nature of the cutting process for all ways of mechanical wood machining is possible to easier understand when the elementary is known. The crosscutting wood is the most widespread in the process of forest exploitation; it is used at tree exploitation, shortening stems and assortment production. The longitudinal cutting is mainly applied in subsidiary enterprises (sawmills) and basic wood industry. Mixed cutting is used in furniture production. At the forest exploitation there comes to its application at the executing the cut on trees underlying harvesting trees by circular saws. Nowadays, the cutting process of wood is considered as technological scheme. It consists of several connected and relatively inseparable parts. (Marko, J., Holík, J., 2000). The technological system called "cutting process" consists of four parts - subsystems (Fig. 1): work-piece (species of wood, humidity, density, toughness, elasticity, temperature, dimensions, etc.), cutting conditions (they present sum of conditions relating to work-piece, cutting tool and cutting mechanism, which are necessary for cutting process initialization), cutting mechanism (it is mechanism of main movement, feed, number of working movements and procedure of their performance, thickness and width of a layer which is cut, cutting angle, speed of cutting movement and feed, cutting forces and friction forces, performance of engines and etc.) and a cutting tool (cutting-wedge angle, number of teeth, material properties, surface roughness, cutting edge length and etc.).

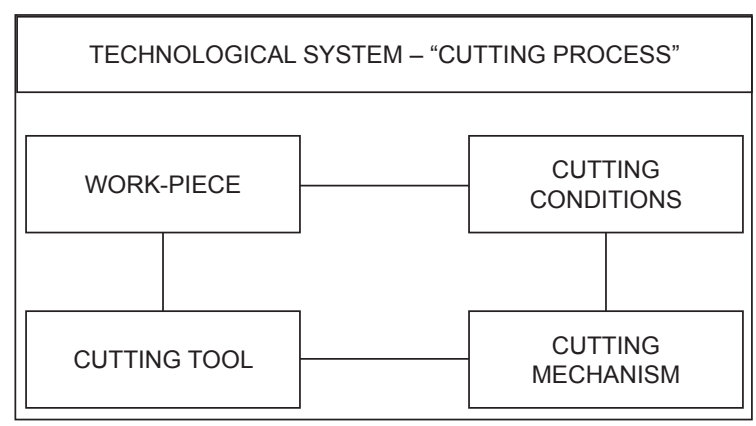

1: The technological system - „the cutting process“ 


\section{Crosscutting wood by circular saws}

Penetrating tooth of a circular saw to wood causes reciprocal action of forces between wood and cutting edge (Fig. 2). The cutting wedge presses on resisting wood. The result is loading frontal, rounded and back surface of cutting wedge. The cutting resistance is resistance, which is created at chip separating by a wedge. The cutting resistance is the reaction on cutting force, it has the same size but opposite direction (Lisičan, 1996).
$F=K \cdot b \cdot h(\mathrm{~N})$

The dimension of cutting work $A_{c}$, in the condition that cutting resistance is constant in all phases of the cutting process, we can define as:

$A_{\mathrm{C}}=F_{\mathrm{C}} \cdot l=K \cdot b \cdot h \cdot l(\mathrm{~J})$,

where:

l...... cutting way of a tooth in the material (mm).

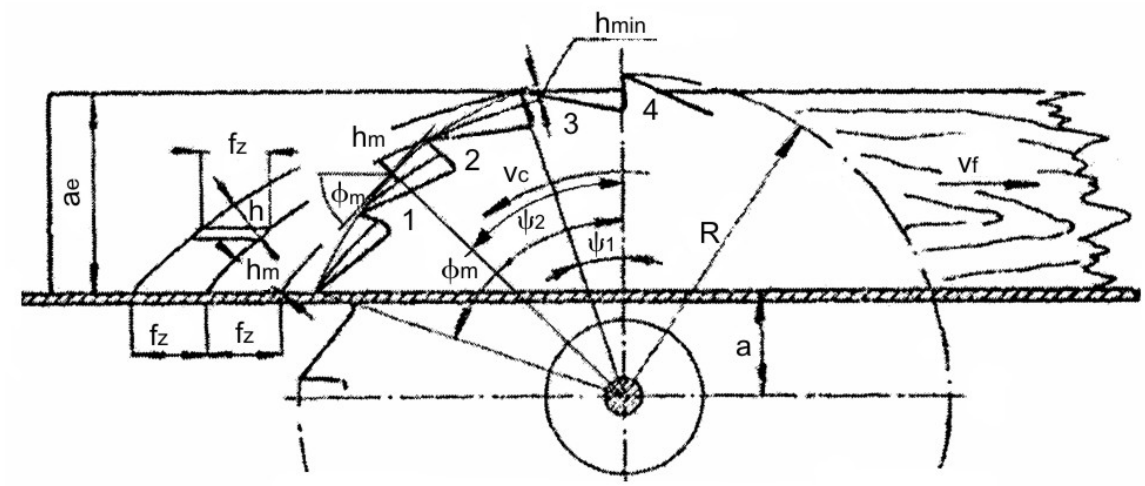

where: $\mathrm{f}_{\mathrm{z}}$ - feed per one tooth [m], $\mathrm{a}_{\mathrm{e}}$ - cutting height [m], $\mathrm{v}_{\mathrm{f}}-$ feeding speed [m.s-1], $\mathrm{v}_{\mathrm{c}}$ - cutting speed [m.s-1], $\psi_{1}-$ incoming angle of a circular saw $\left[{ }^{\circ}\right], \psi_{2}$ - outgoing angle of a circular saw $\left[^{\circ}\right], \phi_{\mathrm{m}}$ - mean angle of cutting fibres $\left[^{\circ}\right], \mathrm{h}_{\mathrm{m}}-$ mean thickness of a chip [mm].

2: The scheme of circular saws cutting

All resistances which cause on cutting-wedge of a circular saw tooth have the resultant force $F$ which is called cutting resistance. It consists of following parts:

- Forces necessary for cutting mass of a work-piece by a cutting-wedge during the deformation of a mass in the surrounding of a cutting edge,

- Forces necessary for deflection of chips and suppression of chip friction against the leading edge of the tooth,

- Forces necessary for suppression of friction on the back and leading surfaces against the machined surface.

Defining the value of individual parts of the force $F$ is quite difficult and depends on many aspects. The part of the force $F$ at the direction of cutting feed $F_{c}$ is called the cutting force and it is used at practical calculations of energetic relations during the cutting process. The part perpendicular on the force $F$, presents the pressure of the circular saw tooth on the surface of machined surface and it is called a withdrawal force $F_{1 w}$. If its value is positive (going down) the material is pressed to the table. If its value is negative (going up) this force picks up the material and it is necessary to provide the stability of the material by pressing mechanism.

Acting cutting force $F_{c}$ on a tooth of a circular saw is taking chips at the width $b$ and thickness $h$. The cutting force value is then given by multiplication of cutting resistance for disintegrated material $\mathrm{K}$ and surface of crosswise chip cutting.
Cutting power is defined as multiplication of cutting force $F_{C}$ and cutting speed $v_{c}$ :

$P_{C}=F_{C} \cdot v_{C}(\mathrm{~W})$.

\section{Cutting conditions at the process of woodcutting by circular saws}

According to the shape of a circular saw in the crosswise cut we can recognize the following circular saws: flat, relieved (called planning), concurrent (on the left or right side or reciprocal) and saddle (on the left or right). Concurrent or saddle parts of circular saws are defined in the course of a workpiece feed against the teeth. According to the cutting course regarding to the way of wooden fibres there are used circular saws for crosswise and longitudinal cuttings. They differ by the teeth profile and the way of sharpening. The teeth profile and the way of sharpening must be according to required performance of a circular saw and the quality of machined surface. They must be according to the type of a work-piece (soft, hard wood and other types of work-pieces) and material of a cutting edge (tool steel, cemented carbide plates).

On each circular saw there are inserted maximum revolutions at the maximum speed $100 \mathrm{~m} . \mathrm{s}^{-1}$. This speed is not working speed but it shows operational reliability, which is guaranteed by a producer. For getting optimal performance of a circular saw there 
is necessary to choose cutting conditions regarding to cut material.

The recommended cutting speeds of a circular saw according to the material are:

- Soft wood 60-100 m.s $\mathrm{s}^{-1}$

- Hard and exotic wood 50-85 m.s $\mathrm{s}^{-1}$

Within the range of recommended cutting speed for chosen material there is oriented according to the requirements on cutting surface quality, technological state of a machine etc. Continuing the recommended cutting speeds does not have practical meaning and it is not recommended for economical reasons. Circular saws have huge construction and the most often they are used in the manipulation links at the manipulation with thin and medium stems (up to $40-50 \mathrm{~cm}$ ). Their advantages are high cutting ability, maintainability and long lifetime.

In the practice there is very important to continue the whole cutting process with the lowest energy consumption. More factors influence energetic consumption e.g. the choice of suitable material for a cutting tool creation, its geometry and optimal cutting conditions (cutting speed $v_{c}$, feeding speed $v_{f}$, feed per one tooth $f_{z}$ ). The cutting power is very important is the factor of energetic consumption. The cutting angles value is together with other cutting conditions decisive for performance of tools, machines, economy of all machining types, and machined surface quality and dimensional exactness of a work-piece. The wrong cutting angles can decline the machined surface quality, get faster the dulling and decrease the lifetime of a tool, increase cutting resistance and influence the lifetime of a machine and efficiency of an operation (Lisičan, Zemiarová; 1988).

\section{The methods for measurement of cutting performance}

The cutting power is possible to measure by more methods (Holopírek, J., Rousek, M.; 2004). There are some of them:

1. The first method: The principle of measurement is based on the change of consumed electric current of an electric engine. There is used power transfer for the change of consumed electric current and it is transferred on analog signal, which is possible to transform using A/D transfer in PC to digital form and then to analyze it by PC program. The way of cutting performance calculation from measured values is arranged as following:

Cutting power is the volume of work done per one second. The unit of power is W. W $=\mathrm{N} \cdot \mathrm{m} \cdot \mathrm{s}^{-1}$.

$P_{c}=F_{c} \cdot v_{c}(\mathrm{~W})$

$P_{c}=\frac{A_{c}}{t}(\mathrm{~W})$.

We can calculate the cutting speed also by torque and the following formula:
$P_{c}=\frac{2 \cdot M_{k} \cdot v_{C}}{D}(\mathrm{~W})$,

where:

$M_{k}$. torque

$D$... diameter of a circulae saw

Calculation between cutting power $P_{c}$ and performance of a machine $P_{p r}$ :

$P_{c}=\frac{P_{P R}}{\eta}(\mathrm{W})$.

2. The second method: The principle of measurement is based on recording the torque on the shaft of driving balance wheel. Torque is defined as multiplication of acting force by the length between point of revolution and center of force. The system SI introduces Newton meter (Nm) as a unit of torque.

The torque value $\mathrm{M}_{\mathrm{k}}$ can be defined by formula:

$M_{k}=F \cdot r(\mathrm{Nm})$,

where:

F.... force

$r$..... radius.

The device records torque and transfers it onto electrical signal. The analyzing technique transforms electrical power on voltage in the range +10 and $-10 \mathrm{~V}$, what depends on the way of torque acting.

3. The third method: The principle of measurement is based on recording engine power at idle running $P_{P O}$, which is used for electromechanical losses suppression of an engine in a gear and wood-working machine bearings. Then it records the power of an engine at the technological operation $P_{P R}$, which is necessary for losses suppression in an engine, losses in gears of a circular saw machine and at technological operation. The cutting power $P_{c}$ is possible to calculate by the formula:

$P_{c}=P_{P R}-P_{P O}(\mathrm{~W})$.

It is necessary to say that in the method No. 1 and method No. 3 there are not obtained such exact results. This is the reason why there is used method No. 2 for obtaining cutting power results.

\section{MATERIAL AND METHODS}

The experimental measuring device was developed for the research of crosswise wood cutting parameters and the cutting tools research. Its scheme is shown in Fig. 3. The measuring equipment consists of two parts i.e. cutting and feeding parts. The cutting part provides development and transfers torque to a tool. The feeding part provides work clamping and feeding wood into the cut.

As it is shown in the scheme there are placed: three-phased asynchronous 7,5 kW electric engine. Its torque is transferred throughout the spindle head to a tool (circular saw). The wood sample is 


\section{Experimental measuring device}

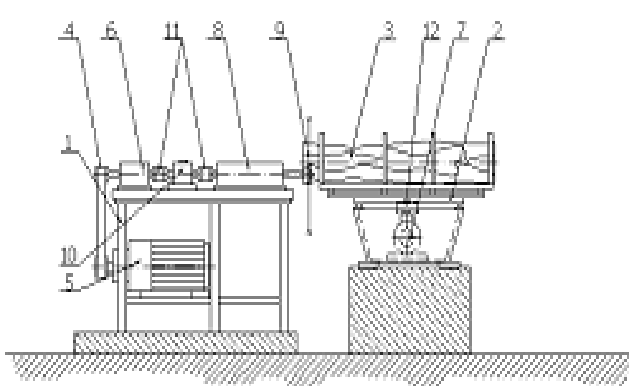

Cutting part Feeding part

3: The scheme of experimental measuring device
1. working table

2. sliding line

3. roumd timber

4. ge ir of be tis for the driving a circular saw

5. electric engine for the driving a circular saw

6. bearing cover

7. electric engine for the driving the material to the out

8. spinde head of a croular $s$ w

9. circular $s a w$

10. recorder T20WN for torques and rewo hitions

11. chitch GFLL-28

12. force recorder $S 2$ caught on the plate in the holder by a lever system, which provides safety holding. The crosswise feeding of the work-piece is provided by $5,5 \mathrm{~kW}$ electric engine throughout a safety clutch and a feed screw. Between nut and plate there is placed a force sensor HBM S2. Measured signal from the force signals and torque is transferred by cables to measuring centre SPIDER-8, which is connected with PC. The torque sensor HBM T20WN enables to register the revolutions of a circular saw. The revolutions and the power of electric engines are regulated by frequency converters with vector control.

At the experimental tests there were used wood samples with the diameter $18 \mathrm{~cm}$ and length $1,5 \mathrm{~m}$. The wood samples were made of beech, oak and spruce. Their moisture was approximately $45 \%$ at spruce, $50-60 \%$ at beech and oak. It was measured by the weighing method. The samples were cut by circular saws made with cemented carbide plates and of high speed steel (their technical parameters are shown in Table I).

The measurement of wood (beech and oak) was made at revolutions of a circular saw $1900 \mathrm{~min}^{-1}$, at the cutting speed $59.66 \mathrm{~m} . \mathrm{s}^{-1}$ and feeding speed $152 \mathrm{~mm} . \mathrm{s}^{-1}$. The feeding speed at wood (spruce) was decreased because of a circular saw jamming at the process of wood cutting. It was $103 \mathrm{~mm} . \mathrm{s}^{-1}$.

\section{RESULTS AND DISCUSSION}

The partial purpose of an experiment was to obtain the influence of different cutting-edge side rakes on the torque value and compressive force to the cut (Fig. 5). The cutting-edge side rake influenced cutting resistance and the whole process of crosswise wood cutting. The results were treated in the program Conmes Spider.

From the torque $M_{k}$ course at cutting of beech by a circular saw made with cemented carbide plates there was possible to see great increase of value at the beginning penetration of a tool (circular saw) to the cut, then there was certain decrease of the value what was caused by inertia of a circular saw and then following fixation of the cutting process. Then the cutting process ran at the certain constant value (the torque value was changed very little), only at the end of cutting process the value reached the state when the circular saw rotated without any loading. The course of torque $M_{k}$ at the cutting process of circular saws made of high speed steel was characterized by high increase to maximal value, then it decreased a little to the certain value and finally it decreased rapidly, what was caused by cutting out the wood.

From the obtained results the torque $M_{k}$ at different cutting-edge side rakes of circular saws made with cemented carbide plates and circular saws made of high speed steel at different wood we reduced maximum values of $M_{k}$ at individual measurements and we made basic statistical results analysis (Table II).

Then we created the graphical evaluation of arithmetic means of maximum values $M_{\mathrm{b}}$, which gives better overview about obtained results. The value of cutting power is calculated from torque due

I: Basic dimension of circular saws

\begin{tabular}{lccccc}
\hline \multicolumn{1}{c}{ Basic dimensions } & $\begin{array}{c}\text { Diameter of } \\
\text { a saw } \\
\mathbf{D}(\mathbf{m m})\end{array}$ & $\begin{array}{c}\text { Width of a saw } \\
\mathbf{B}(\mathbf{m m})\end{array}$ & $\begin{array}{c}\text { Cutting- } \\
\text { clearance angle } \\
\alpha\left(^{\mathbf{0}}\right)\end{array}$ & $\begin{array}{c}\text { Cutting-edge } \\
\text { side rake } \\
\left({ }^{\mathbf{(}}\right)\end{array}$ & No. of teeth \\
\hline $\begin{array}{l}\text { Circular saw made of high } \\
\text { speed steel }\end{array}$ & 600 & 5,4 & 20 & $-5,0,5,10$ & 56 \\
$\begin{array}{l}\text { Circular saw made with } \\
\text { cemented carbide plates }\end{array}$ & 600 & 5,4 & 15 & $-10,0,10,20$ & 54 \\
\hline
\end{tabular}




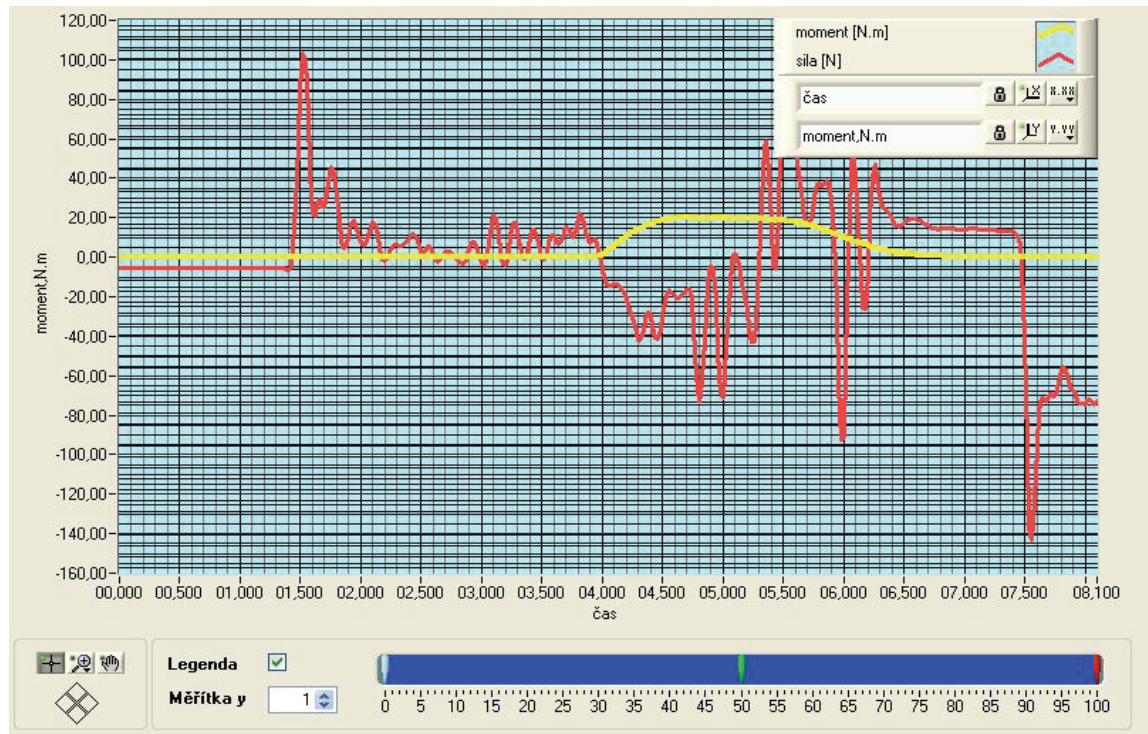

5: The course of $M_{k}$ and compressive force to the cutting at the crosscutting wood (beech)

II: Values of arithmetic means for maximal values of $P_{C}$ at individual values of a cutting-angle side rake on circular saws

\begin{tabular}{|c|c|c|c|c|c|c|c|c|}
\hline \multirow{3}{*}{$\begin{array}{l}\text { Species of wood/ } \\
\text { cutting-edge side } \\
\text { rake }\left({ }^{\circ}\right)\end{array}$} & \multicolumn{8}{|c|}{ Value of cutting power $\mathrm{Pc}(\mathrm{kW})$} \\
\hline & \multicolumn{4}{|c|}{ Circular saw made of high speed steel } & \multicolumn{4}{|c|}{ Circular saw made of cemented carbide plates } \\
\hline & 10 & 5 & $\mathbf{0}$ & -5 & 20 & 10 & 0 & -10 \\
\hline beech & 3.5875 & 3.8342 & 4.0389 & 4.0947 & 3.9813 & 3.8919 & 3.9554 & 4.0011 \\
\hline oak & 3.7427 & 3.8898 & 4.1126 & 4.1305 & 4.0648 & 3.7805 & 3.9057 & 4.0131 \\
\hline spruce & 3.8063 & 3.9833 & 4.1245 & 4.1046 & 4.2219 & 3.9077 & 3.9833 & 4.1921 \\
\hline
\end{tabular}

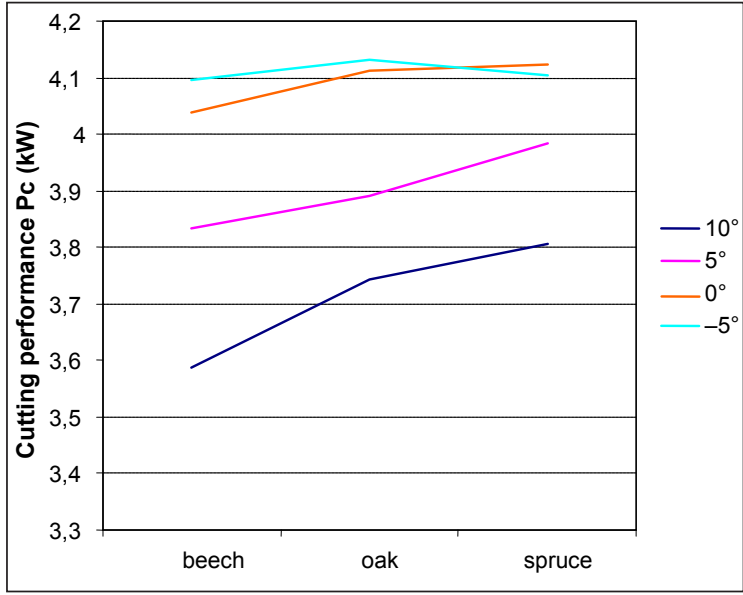

6: The value of cutting performance $P$ at the process of the crosscutting wood by circular saw made of high speed steel

to the diameter of a circular saw $\mathrm{D}=600 \mathrm{~mm}$ and the cutting speed $v=59.66 \mathrm{~m} . \mathrm{s}^{-1}$.

The shown graphical analysis of measurement results oriented to torque $\mathrm{M}_{\mathrm{k}}$ and cutting power at certain cutting-edge side rake confirmed that the best

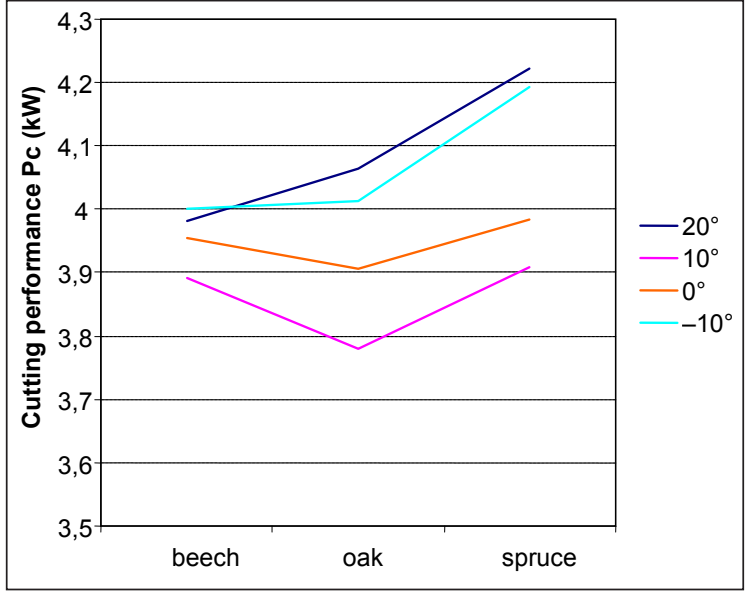

7: The value of cutting performance $P$ at the process of the crosscutting wood by circular saw made with cemented carbide plates

value for a cutting-edge side rake at the crosswise wood cutting by circular saw made with cemented carbide plates and circular saws made of high speed steel is positive value $\left(10^{\circ}\right)$ what other research for crosswise wood cutting confirms, too. 


\section{SUMMARY}

In the practice there is very important that the whole process of wood cutting should run with the lowest energy consumption of the whole process. There are many factors which influence its energetic consumption e.g. a cutting tool material, its geometry and optimal cutting forces (cutting speed $v_{c}$, feeding speed $v_{f}$ ). The cutting power is very important factor of energetic consumption. Utilization of circular saws with unsuitable technical and technological parameters in the given conditions of work can be expressed by following deficiencies: fast circular saw wearing and bad quality of the cut, higher energetic consumption, higher wood consumption in the process of production because there are necessary big additions for machining.

In this article we dealt with influence of chosen cutting parameters (geometry of cutting edge, wood type, a circular saw type) on energetic consumption (cutting power $P_{C}$ ) of a technical device. The establishment of torque value and feeding power (cutting power) at the crosswise wood cutting process has very big meaning for designers of cross-cutting lines. The possibility of calculation cutting power verification of the torque measurement and the design of circular saw teeth has big influence on economical and time consuming aspect at the making different wood assortments. The conditions at the experiments were approximate to the working conditions of real machines and the results of individual experiments are possible to compare with the results obtained at the similar experimental workstations.

\section{SÚHRN}

\section{Analýza vplyvu geometrie reznej hrany zubov pílových kotúčov na proces priečneho} delenia dreva

V praxi je vel'mi dôležité aby celý proces rezania dreva prebiehal, z čo najmenšími nárokmi na energiu (teda energetickú náročnost' celého procesu). Na energetickú náročnost' strojného zariadenia vplývajú viaceré faktory, akými sú napríklad výber vhodného materiálu rezného nástroja, jeho geometrie a tiež optimálne rezné podmienky (rezná rýchlost $\mathrm{v}_{\mathrm{c}}$, rýchlost' posuvu $\mathrm{v}_{\mathrm{f}}$ ). Vel'mi dôležitý faktor energetickej náročnosti je rezný výkon. Používanie pílových kotúčov s nevhodnými technickými a technologickými parametrami v daných podmienkach práce sa prejaví naraz viacerými nedostatkami a to: rýchlym opotrebovaním pílového kotúča a následne zlou kvalitou rezu, zvýšením energetickej náročnosti, zvýšením spotreby suroviny na plánovaný objem výroby, pretože sú potrebné vel'ké nadmiery na opracovanie.

V tomto článku sme sa zaoberali vplyvom vybraných rezných parametrov (geometria reznej hrany, druh dreviny, typ pílového kotúča) na energetickú náročnost' (rezný výkon $\mathrm{P}_{\mathrm{C}}$ ) strojného zariadenia. Stanovenie vel'kosti krútiaceho momentu a podávacej sily (rezného výkonu) priečnom rezaní dreva má vel'ký význam pre konštruktérov deliacich uzlov manipulačných liniek. Možnost' overenia správneho výpočtu rezného výkonu z merania krútiaceho momentu a konštrukcie zubov pílových kotúčov má vel'ký vplyv z ekonomického a časového hl'adiska pri výrobe rôznych sortimentov dreva. Podmienky pri experimentoch boli priblížené k pracovným podmienkam reálnych strojov a výsledky jednotlivých experimentov je možné porovnávat s výsledkami dosiahnutými na iných podobných výskumných pracoviskách.

priečne delenie dreva, kotúčové píly, geometria reznej hrany, rezný výkon

\section{REFERENCES}

HOLOPÍREK, J., ROUSEK, M., 2004: Comparison of the theoretical calculation of resistance in cutting particleboards with an experiment. In: Trieskové a beztrieskové obrábanie dreva `04. Zborník prednášok IV. MVK Trieskové a beztrieskové obrábanie dreva, 14.-16. október Starý Smokovec 2004, s. 99-104.
LISIČAN, J. a kol., 1996: Teória a technika spracovania dreva. MATCENTRUM Zvolen, 626 s. ISBN 80-967315-6-4.

LISIČAN, J.,ZEMIAROVÁ, B., 1988: Obrábanie a delenie drevných materiálov. Návody na cvičenia, ES VŠLD, Zvolen. 1988.

MIKLEŠ, M., MARKO, J., 1992: Teória a stavba lesných strojov l. ES TU, Zvolen. 1992.

MARKO, J., HOLÍK, J., 2000: Teória delenia dreva. ES TU, Zvolen. 2000.

Ing. Ján Kováč, PhD., prof. Ing. Milan Mikleš, DrSc., Katedra lesnej a mobilnej techniky, Fakulta environmentálnej a výrobnej techniky, Technická univerzita vo Zvolene, T. G. Masaryka 24, 96053 Zvolen, Slovenská republika, e-mail:kovac@vsld.tuzvo.sk, mikles@vsld.tuzvo.sk 